\title{
A comparison of Effect of Iron Deficiency Anemia on HbA1c Levels in Controlled Diabetics and Non-diabetics: A Cross Sectional Analysis of 300 Cases
}

\author{
Lavanya Rajagopal ${ }^{1 *}$, Sundaram Arunachalam¹, Shivashekar Ganapathy', Balaji Ramraj² and Veena Raja ${ }^{3}$ \\ ${ }^{1}$ Department of Pathology, SRM Medical College Hospital and Research Centre, Kattankulathur, Chennai India \\ ${ }^{2}$ Department of community medicine, SRM Medical College Hospital and Research Centre, Kattankulathur, Chennai India \\ ${ }^{3}$ Department of Pathology, SRM Medical College Hospital and Research Centre, Kattankulathur, Chennai India
}

\begin{abstract}
Background: Diabetes Mellitus (DM) has become a major health problem worldwide. American Diabetes Association has considered $\mathrm{HbA1C}$ levels $\leq 6.5 \%$ as the prime target for glycemic control and as a diagnostic criterion for DM. Anemia is common in DM (8-66\%). Studies on alteration of $\mathrm{HbA} 1 \mathrm{C}$ in IDA have conflicting results.

Objectives: To identify and compare the effect of IDA on HbA1C levels among controlled diabetics (Fasting plasma glucose (FPG) $<126 \mathrm{mg} /$ dl since last 6 months) and non-diabetics and its variation according to the degree of anemia.

Methods: This cross-sectional study done in SRM Medical College Hospital and Research Centre, Chennai includes 150 Controlled diabetics ( 75 with IDA and 75 without IDA) and 150 non diabetics ( 75 with IDA and 75 without IDA). HbA1C, complete hemogram, iron profile and FPG were tested. Medical history was recorded.

Results: The mean HbA1C in controlled diabetics with and without IDA were $8.81 \pm 0.13 \& 5.79 \pm 0.01$ respectively $(\mathrm{P}<0.05)$ and in nondiabetics with and without IDA were $6.84 \pm 0.07 \& 5.12 \pm 0.04$ respectively $(\mathrm{P}<0.05)$. The difference between no, mild, moderate and severe anemia in both diabetics and non-diabetics was statistically significant $(\mathrm{p}<0.05)$. Mean $\mathrm{HbA} 1 \mathrm{C} \%$ was highest in groups with severe anemia.

Conclusion: IDA falsely elevates $\mathrm{HbA} 1 \mathrm{C}$ level independent of blood glucose concentration in both controlled diabetics and non-diabetics. Hence prior to alteration of treatment regimen based on $\mathrm{HbA1C}$ for diabetes, IDA should be diagnosed and corrected. Concurrent evaluation for anemia is critical to correctly interpret glycemic status in Indian population with prevalent IDA.
\end{abstract}

Keywords: $H b A_{1} C$, Iron deficiency Anemia, Diabetics, Non-diabetics

\section{Introduction}

Diabetes has become a major health problem worldwide with an estimated 300 million people to be diagnosed with the disease in the next 10 years and 370 million by 2030. ${ }^{[1]}$ In 2010, American Diabetes Association (ADA) has considered $\mathrm{HbA}_{1} \mathrm{C}$ levels as the prime target for glycemic control and as a diagnostic criterion for Diabetes Mellitus (DM). $\mathrm{HbA}_{1} \mathrm{C} \geq 6.5 \%$ has been established for the diagnosis of DM for its high specificity and certified by the World Health Organization (WHO) in 2011. ${ }^{[1,2,3]}$ Anemia is common among DM and its incidence ranges from $8-66 \% \cdot{ }^{[4]}$ Several mechanisms have been discussed about the association of anemia in DM and its complications like nephropathy. ${ }^{[5,6]}$

Initially it was believed that $\mathrm{HbA}_{1} \mathrm{C}$ was affected only by blood glucose levels. ${ }^{[4,5]}$ However certain study results have proven that $\mathrm{HbA1C}$ levels are altered by various other co-existing factors, along with DM, especially that of IDA which is a major public health problem in developing countries like India. Other factors interfering with $\mathrm{HbA}_{1} \mathrm{C}$ levels are hemoglobinopathies, renal impairment, pregnancy, hypothyroidism, hemolytic anemia etc. Christy AL et al reported that controlled plasma glucose levels for last 3 months correlates well with controlled $\mathrm{HbA}_{1} \mathrm{C}(<6.5 \%) .{ }^{[7]}$

One of the well-known pathological ill effects of IDA in the biological system is the glycosylation of proteins. ${ }^{[8]}$ Although different studies have been carried out to analyze the influence of IDA on HbA1C levels in both diabetic and non-diabetic population individually, only very few studies have been conducted comparing $\mathrm{HbA}_{1} \mathrm{C}$ variation in both these groups. Due to the variation in the results of multiple studies, we decided to investigate and compare the effects of IDA on $\mathrm{HbA}_{1} \mathrm{C}$ levels in both controlled diabetic and non-diabetic Indian adults.

\section{Materials and Methods}

In this cross-sectional study, we collected data of 1360 individuals aged >18years who consulted our SRM 
Medical College Hospital and Research Centre, Chennai, Tamil Nadu between February 2016 to November 2016.

Of the 1360 persons enrolled in this study, 230 were diabetics and 1130 were non-diabetics. After exclusion of individuals with hypothyroidism, renal insufficiency (elevated serum urea, creatinine), hemoglobinopathies, Pregnancy, Fasting plasma glucose (FPG) $>126$ mg/dl, hemolytic anemia and those who completed laboratory investigations, 170 controlled diabetics (FPG level is $<126$ $\mathrm{mg} / \mathrm{dl}$ since last 6 months) and 365 non diabetics were finalized for our study.

Among 170 controlled diabetics, 95 were anemic (56\%) out of which 75 were diagnosed as IDA and others were excluded. Among 365 non-diabetics, 90 were anemic. Out of 90 nondiabetics with anemia, 75 had IDA and others were excluded. Patients with IDA were chosen by their hemoglobin level $(\mathrm{Hb}<13 \mathrm{gm} \%$ in males and $<12 \mathrm{gm} \%$ in females) based on definition of WHO and with predominantly microcytic indices [Mean Corpuscular Volume $(\mathrm{MCV})<76 \mathrm{fl}$ ], hypochromic indices [Mean corpuscular Hemoglobin $(\mathrm{MCH})<27 \mathrm{pg} /$ cell] and [Mean Corpuscular Hemoglobin Concentration (MCHC) $<32$ $\mathrm{g} / \mathrm{dl}$ ], and microcytic hypochromic picture in peripheral smear. This is later confirmed by low serum iron $(<59 \mu \mathrm{g} /$ $\mathrm{dl}$ in males and $<37 \mu \mathrm{g} / \mathrm{dl}$ in females) \& low serum ferritin $(<15 \mathrm{ng} / \mathrm{ml}$ in males and $<9 \mathrm{ng} / \mathrm{ml}$ in females $) .{ }^{[9]}$

Age, Sex and FPG matched controls were selected for each group and the data results were analyzed. Blood samples from both groups were tested for $\mathrm{FPG}, \mathrm{HbA}_{1} \mathrm{C}, \mathrm{Hb}, \mathrm{RBC}$ count, Hct, MCV, MCH, MCHC, Serum iron and Ferritin. Medical history was recorded

On the basis of hemoglobin level, anemic patients were further categorized as Mild anemia (male 12-12.9 gm/dl and female 11-11.9gm/dl), Moderate anemia (male 9-11.9 $\mathrm{gm} / \mathrm{dl}$ and female 8-10.9 gm/dl) and Severe anemia (male $<9 \mathrm{gm} / \mathrm{dl}$ and female $<8 \mathrm{gm} / \mathrm{dl})$.

Measurements: $\mathrm{Hb}, \mathrm{MCV}, \mathrm{MCH}, \mathrm{MHC}$ were estimated by SYSMEX XT-1800i analyzer. $\mathrm{HbA}_{1} \mathrm{C}$ estimated by HPLC method in Bio-Rad D10 analyzer. Glucose oxidase / peroxidase method for plasma glucose and serum iron
(TPTZ method), serum ferritin (Bio-Rad Quanimune Ferrin IRMA, Bio-Rad lab)

Statistical Analysis: The data are presented as mean \pm S.D for continuous variables. Group means were compared by student t-test. Pearson's co-efficient of correlation was used to determine the correlation between two variables. $p$ value $<0.05$ was considered significant.

\section{Results}

The mean $\mathrm{HbA}_{1} \mathrm{C}$ in controlled diabetics with and without IDA were $8.81 \pm 0.13 \& 5.79 \pm 0.01$ respectively and in non-diabetics with and without IDA were $6.84 \pm 0.07 \&$ $5.12 \pm 0.04$ respectively. This result show that the mean $\mathrm{HbA}_{1} \mathrm{C}$ was higher in those with IDA than in those without IDA in both diabetics and non-diabetics which was statistically significant $(\mathrm{p}<0.05)$ in both groups. [Table1/ Fig 1]. The mean $\mathrm{Hb}$, Hct, $\mathrm{MCV}, \mathrm{MCH} \& \mathrm{MCHC}$ in controlled diabetics with and without IDA were statistically significant p $(<0.05)$. [Table 2]

Among controlled diabetics, 11 had mild anemia with mean $\mathrm{HbA}_{1} \mathrm{C} \%$ of $7.40 \pm 0.70,39$ had moderate anemia with mean $\mathrm{HbA}_{1} \mathrm{C} \%$ of $8.50 \pm 0.11$ and 25 had severe anemia with mean $\mathrm{HbA}_{1} \mathrm{C} \%$ of $9.15 \pm 0.17$. Similarly in non-diabetics, 40 had mild anemia with mean $\mathrm{HbA}_{1} \mathrm{C} \%$ of $6.57 \pm 0.09 \%, 28$ had moderate anemia with mean $\mathrm{HbA}_{1} \mathrm{C} \%$ of $7.19 \pm 0.11$ and 7 had severe anemia with mean $\mathrm{HbA}_{1} \mathrm{C} \%$ of $8.31 \pm 0.01 \%$.

The mean serum iron and ferritin levels in controlled diabetics with and without IDA were $32.68 \pm 0.71 \mu \mathrm{g} /$ $\mathrm{dl}, 10.06 \pm 0.79 \mu \mathrm{g} / \mathrm{l}$ and $75.26 \pm 0.79 \mu \mathrm{g} / \mathrm{dl}, 45.19 \pm 1.11 \mu \mathrm{g} / \mathrm{l}$ respectively which was statistically significant $(\mathrm{p}<0.05)$. The mean serum iron and ferritin levels in non-diabetics with and without IDA were $42 \pm 0.61 \mu \mathrm{g} / \mathrm{dl}, 12.09 \pm 1.21$ $\mu \mathrm{g} / \mathrm{l}$ and $74 \pm 0.32 \mu \mathrm{g} / \mathrm{dl}, 41.06 \pm 0.43 \mu \mathrm{g} / \mathrm{l}$ respectively which was statistically significant $(\mathrm{p}<0.05)$.

The difference was statistically significant $(\mathrm{p}<0.05)$ between no, mild, moderate and severe anemia in both controlled diabetics and non-diabetics and moreover mean $\mathrm{HbA}_{1} \mathrm{C} \%$ was higher in groups with severe anemia in relation to $\mathrm{HbA}_{1} \mathrm{C}$ levels in patients without IDA. [Table 3/Fig 2]

TABLE 1: COMPARISON OF HbA1C\% BETWEEN ANEMIC AND NOT ANEMIC IN CONTROLLED DIABETICS \& NONDIABETICS.

\begin{tabular}{|c|c|c|c|c|c|}
\hline & Parameters & IDA & Not anemic & T test & P value \\
\hline Controlled diabetics & $\mathrm{HbA}_{1} \mathrm{C} \%$ & $8.81 \pm 0.13$ & $5.79 \pm 0.01$ & 23.974 & $<0.05$ \\
\hline Non-diabetics & $\mathrm{HbA}_{1} \mathrm{C} \%$ & $6.84 \pm 0.07$ & $5.12 \pm 0.04$ & 22.219 & $<0.05$ \\
\hline
\end{tabular}


TABLE 2: Comparison of Red Cell Indices Between Anemic and Not Anemic in Controlled Diabetics \& Nondiabetics

\begin{tabular}{|c|c|c|c|c|c|}
\hline PARAMETERS & SUBJECTS & IDA & NOT ANAEMIC & T TEST & P VALUE \\
\hline \multirow{2}{*}{$\mathrm{Hb}(\mathrm{g} / \mathrm{dl})$} & Controlled diabetics & $9.22 \pm 0.23$ & $13.83 \pm 0.13$ & -17.483 & $<0.05$ \\
\hline & Non diabetics & $11.46 \pm 0.08$ & $14.31 \pm 0.16$ & -16.078 & $<0.05$ \\
\hline \multirow{2}{*}{ Hct $(\%)$} & Controlled diabetics & $31.35 \pm 0.71$ & $41.61 \pm 0.45$ & -12.221 & $<0.05$ \\
\hline & Non diabetics & $37.07 \pm 0.29$ & $42.20 \pm 0.47$ & -9.328 & $<0.05$ \\
\hline \multirow{2}{*}{$\operatorname{MCV}(\mathrm{fl})$} & Controlled diabetics & $66.79 \pm 1.53$ & $87.40 \pm 0.51$ & -12.791 & $<0.05$ \\
\hline & Non diabetics & $78.56 \pm 0.22$ & $86.19 \pm 0.59$ & -3.425 & $<0.05$ \\
\hline \multirow{2}{*}{$\mathrm{MCH}$ (pg/cell) } & Controlled diabetics & $23.88 \pm 0.50$ & $29.04 \pm 0.14$ & -9.910 & $<0.05$ \\
\hline & Non diabetics & $27.17 \pm 0.33$ & $29.75 \pm 0.21$ & -6.511 & $<0.05$ \\
\hline \multirow{2}{*}{$\mathrm{MCHC}$} & Controlled diabetics & $29.29 \pm 0.29$ & $32.72 \pm 0.08$ & -11.409 & $<0.05$ \\
\hline & Non diabetics & $29.29 \pm 0.29$ & $32.72 \pm 0.08$ & -11.409 & $<0.05$ \\
\hline
\end{tabular}

TABLE 3: $\mathrm{HbA}_{1} \mathrm{C}$ Variation According to The Degree of Anemia

\begin{tabular}{|c|c|c|c|c|}
\hline \multirow{2}{*}{ DEGREE OF ANEMIA } & \multicolumn{2}{|c|}{ CONTROLLED DIABETICS } & \multicolumn{2}{c|}{ NONDIABETICS } \\
\cline { 2 - 5 } & NUMBER & MEAN HBA ${ }_{1} \%$ & NUMBER & $5.16 \pm 0.04$ \\
\hline NO & 75 & $5.79 \pm 0.01$ & 40 & $6.57 \pm 0.09$ \\
\hline MILD & 10 & $7.40 \pm 0.70$ & 30 & $7.19 \pm 0.11$ \\
\hline MODERATE & 40 & $8.50 \pm 0.11$ & 5 & $8.01 \pm 0.01$ \\
\hline SEVERE & 25 & $9.15 \pm 0.17$ & MEAN HBA $\%^{\prime}$ \\
\hline
\end{tabular}

\section{CONTROLLED DIABETICS}

ANOVA - 202.613, p - 0.0001

No anemia to mild anemia, T test: $-7.591, \mathrm{p}-0.0001$

Mild anemia to Moderate anemia, T test: $-3.306, \mathrm{p}-0.001$

Moderate anemia to Severe anemia, T test: $-5.805, \mathrm{p}-0.0001$

\section{NON DIABETICS}

ANOVA - 229.815, p - 0.0001 .

No anemia to mild anemia, T test: $-14.323, \mathrm{p}-0.0001$

Mild anemia to Moderate anemia, T test: $-4.483, \mathrm{p}-0.0001$

Moderate anemia to Severe anemia, T test: $-3.397, \mathrm{p}-0.0001$

TABLE 4: Comparison of Present Study Hba ${ }_{1}$ Levels with Previous Studies Having Similar Results [Diabetics]

\begin{tabular}{|c|c|c|c|c|c|c|}
\hline Study & Year & Glycemic status & Number screened & IDA & Not-anemic & Significance \\
\hline Tarim et al $^{11}$ & 1999 & DM & 37 & $10.1 \pm 2.7$ & $8.2 \pm 3.1$ & $\mathrm{p}<0.05$ \\
\hline Ng et al $^{13}$ & 2010 & DM & 15 & $7.4 \pm 0.2$ & $6.9 \pm 0.1$ & $\mathrm{p}<0.05$ \\
\hline Christy et al $^{15}$ & 2014 & DM & 120 & $6.8 \pm 1.4$ & $5.6 \pm 0.6$ & $\mathrm{p}<0.05$ \\
\hline Present study & 2016 & DM & 150 & $8.8 \pm 0.1$ & $5.7 \pm 0.01$ & $\mathrm{p}<0.05$ \\
\hline
\end{tabular}

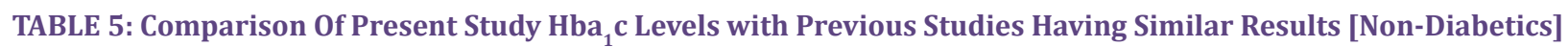

\begin{tabular}{|c|c|c|c|c|c|}
\hline Study & Year & Number screened & IDA & Not-anemic & Significance \\
\hline El-Agouza et al $^{6}$ & 2002 & 81 & $6.1 \pm 0.6$ & $5.2 \pm 0.4$ & $\mathrm{p}<0.05$ \\
\hline Coban et al $^{12}$ & 2004 & 100 & $7.4 \pm 0.8$ & $5.9 \pm 0.5$ & $\mathrm{p}<0.05$ \\
\hline Shanthi et al $^{11}$ & 2013 & 100 & $7.6 \pm 0.5$ & $5.5 \pm 0.8$ & $\mathrm{p}<0.05$ \\
\hline Silva et al $^{14}$ & 2015 & 122 & $5.6 \pm 0.4$ & $5.3 \pm 0.4$ & $\mathrm{p}<0.05$ \\
\hline Present study & 2016 & 150 & $6.8 \pm 0.07$ & $5.1 \pm 0.04$ & $\mathrm{p}<0.05$ \\
\hline
\end{tabular}


TABLE 6: Previous Studies with Contradicting $\mathrm{Hba}_{1} \mathrm{c}$ Results from The Present Study [Non-Diabetics]

\begin{tabular}{|c|c|c|c|c|c|c|}
\hline Study & Year & Glycemic status & Number screened & IDA & Not-anemic & Significance \\
\hline Ford ES et al ${ }^{17}$ & 2011 & NDM & 8296 & $5.5 \pm 0.1$ & $5.4 \pm 0.2$ & $p>0.05$ \\
\hline Sinha et al ${ }^{18}$ & 2012 & NDM & 100 & $4.6 \pm 0.6$ & $5.5 \pm 0.6$ & $p>0.05$ \\
\hline Kalasker et al ${ }^{19}$ & 2014 & NDM & 80 & $5.9 \pm 0.4$ & $6.5 \pm 0.3$ & $p>0.05$ \\
\hline
\end{tabular}

TABLE 7: Comparison of Study Results Showing Hba ${ }_{1}$ Variation According to The Degree of Anemia

\begin{tabular}{|c|c|c|c|c|c|c|c|}
\hline \multirow{2}{*}{ Study } & \multirow{2}{*}{ Year } & \multirow{2}{*}{ Number screened } & \multicolumn{4}{|c|}{ Degree of Anemia } & \multirow{2}{*}{ Significance } \\
\hline & & & No & Mild & Moderate & Severe & \\
\hline Silva et $\mathrm{al}^{20}$ & 2015 & 122 & $5.3 \pm 0.40$ & $5.5 \pm 0.40$ & $5.6 \pm 0.40$ & $5.7 \pm 0.40$ & $P<0.05$ \\
\hline Present study & 2016 & 150 & $5.1 \pm 0.04$ & $6.5 \pm 0.09$ & $7.1 \pm 0.11$ & $8.0 \pm 0.01$ & $P<0.05$ \\
\hline
\end{tabular}

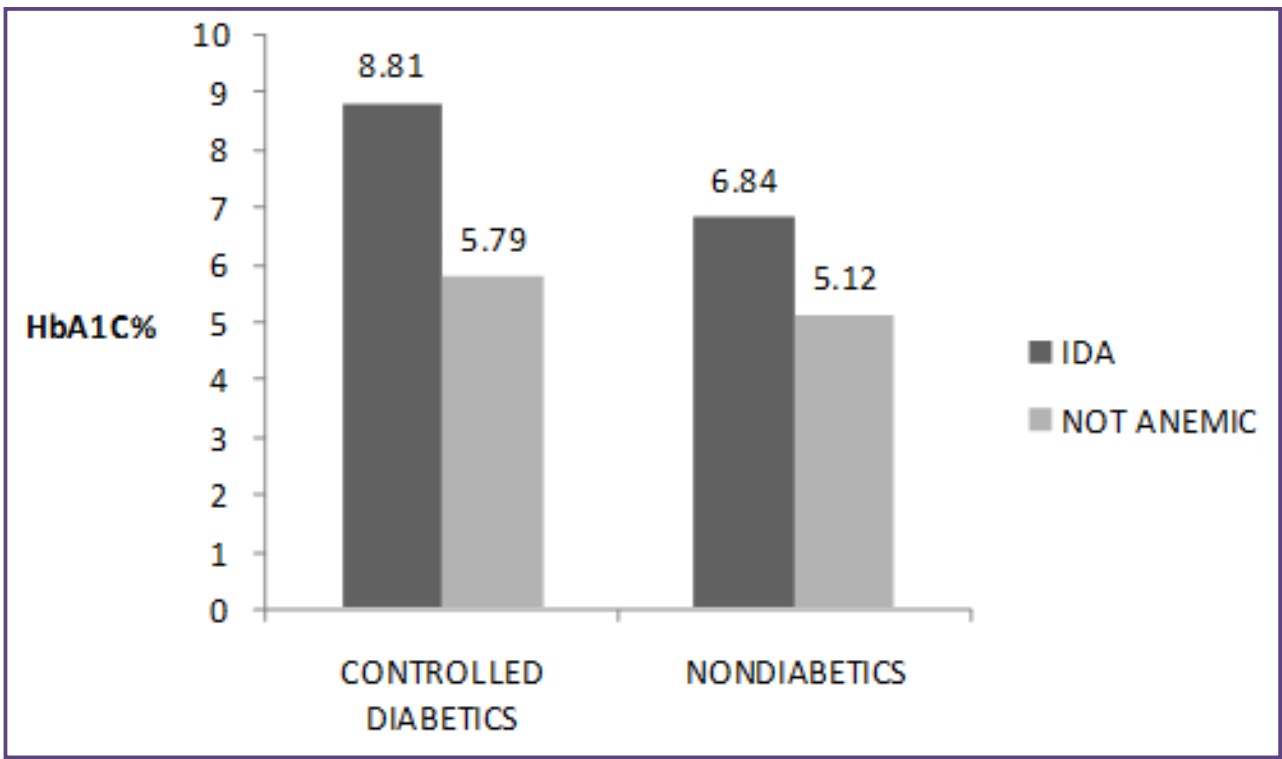

Fig. 1: Comparison of Hba1c\% in Study Groups with and Without Anemia.

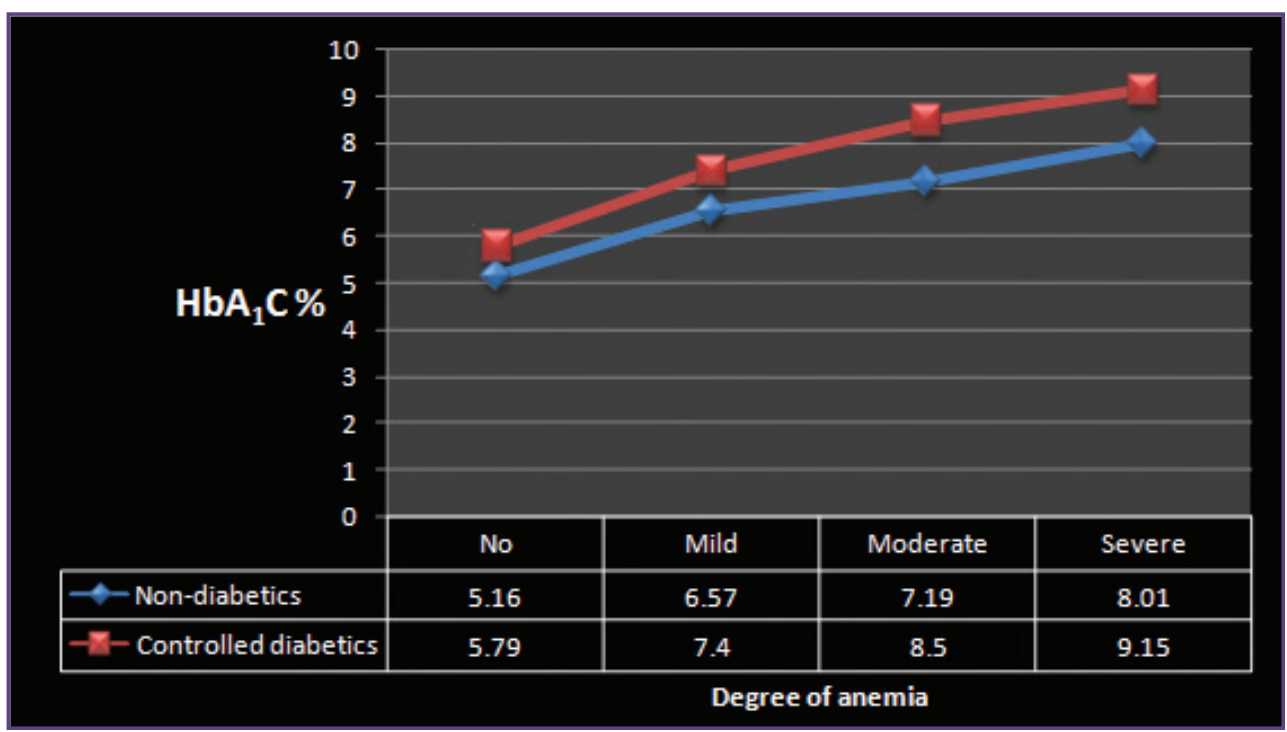

Fig 2: $\mathrm{HbA}^{1} \mathrm{C}$ Variation in Mild, Moderate And Severe Anemia. 


\section{Discussion}

Glycated hemoglobin reflects the glycemic status when monitored over 3 months and predicts the risk of long term complications in diabetics. Glycation of the $\mathrm{NH} 2$ terminal valine residue of the $\beta$-chain of hemoglobin results in the formation of $\mathrm{HbA}_{1} \mathrm{C}$. It also identifies individuals who are at high risk for developing diabetes ${ }^{[10]}$ According to many study results, anemia is almost twice common in diabetics than non-diabetics. ${ }^{[4,11,12]}$ Apart from blood glucose, $\mathrm{HbA1c}$ levels can be affected by factors unrelated to diabetes like IDA. ${ }^{[13]}$

Increased $\mathrm{HbA}_{1} \mathrm{C}$ levels in IDA were explained by a) Quaternary structure of hemoglobin is altered leading to rapid glycation of globin chain.$^{[14,15]}$ b) Increase in the glycated fraction of hemoglobin due to decrease in total hemoglobin at a constant glucose level occurs because $\mathrm{HbA}_{1} \mathrm{C}$ is measured as a percentage of total Hemoglobin A. ${ }^{[16]}$ c) higher average age of circulating erythrocytes noticed in IDA due to reduced red cell production lead to increased $\mathrm{HbA}_{1} \mathrm{C}$ levels. ${ }^{[14]}$

Anemia is a major risk factor for cardiovascular complications and diabetic retinopathy in diabetes. But only very few studies has investigated whether IDA alter the value of $\mathrm{HbA}_{1} \mathrm{C}$ till now inspite being widely used as a diagnostic tool for DM . Thus leading to over or under diagnosis of DM when diagnosed based on the cutoff value $<6.5 \%$ of $\mathrm{HbA} 1 \mathrm{C}$ as approved by ADA..$^{[4,5,17]}$

The results of this study show that $\mathrm{HbA}_{1} \mathrm{C}$ levels are spuriously elevated in the presence of IDA independent of blood glucose concentration in both controlled diabetics and non-diabetics. Our finding confirms the study results of Tarim et al, who reported $\mathrm{HbA}_{1} \mathrm{C}$ level is elevated in diabetics with IDA than with iron-sufficient controls. This may be explained by iron deficiency related changes in the quaternary structure of hemoglobin molecule increasing the glycation of globin chain. ${ }^{[18]}$ This result also coincides with the study results of Christy et al who also observed that $\mathrm{HbA}_{1} \mathrm{C}$ levels were significantly higher in IDA patients and decreased after treatment with iron. ${ }^{[7]} \mathrm{Ng}$ et al concluded that iron and Erythropoietin stimulating agents in diabetic patients cause a significant fall in $\mathrm{HbA} 1 \mathrm{C}$ values without a change in glycemic control. ${ }^{[19]}$ [Table 4]

Our results contradicts with the study results of Sharifi et al, who reported that there was no correlation between serum iron, serum ferritin and $\mathrm{HbAlc}$ in diabetic patients of either sex. Ferritin levels in patients with DM is high, but not related to levels of $\mathrm{HbAlc}$ and blood glucose control. ${ }^{[20]}$ Ford ES et al concluded that there was no evidence of difference in the relationship between fasting glucose and $\mathrm{HbAlc}$ when groups of anemic and non-anemic diabetic individuals with and without iron deficiency when examined individually. ${ }^{[21]}$

Our study results are also consistent with the study done by El-Agouza et al in non-diabetics who reported that a decline in the $\mathrm{Hb}$ level might lead to increase in the glycated fraction at a fixed glucose level, because $\mathrm{HbA}_{1} \mathrm{C}$ is measured as a percentage of total $\mathrm{Hb}{ }^{[16]}$ Our results were also in concordance with the study results of Shanthi et al, Coban et al, and Silva et al. ${ }^{[15,22,23]}$ Coban et al showed a very large difference between $\mathrm{HbA}_{1} \mathrm{C}$ levels in nondiabetic patients with and without IDA. ${ }^{[22]}$ Shanthi et al conducted study in non-diabetics and reported that iron deficiency was associated with higher proportions of $\mathrm{HbA} 1 \mathrm{C}$ and suggested that iron status must be considered during the interpretation of the $\mathrm{HbAlc}$ concentrations in Diabetes mellitus. ${ }^{[15]}$ Silva et al reported that IDA affects HbAlc levels and causes spurious increase in their results. Although these upward changes in $\mathrm{HbA} 1 \mathrm{c}$ values are statistically significant, they may be not clinically relevant when the overall variability of the HbA1c test is considered. This effect is dependent on anaemia degree and the presence of mild anaemia is likely to have a minor effect on HbA1c levels. ${ }^{[23]}$ [Table 5]

Studies by Ford ES et al reported no significant difference in mean $\mathrm{HbA} 1 \mathrm{C}$ concentration according to the IDA status as well as before and after iron treatment. ${ }^{[2]}$ Sinha et al and Kalaskar et al contradicts with our results reporting that $\mathrm{HbA}_{1} \mathrm{C}$ levels are lowered in IDA. ${ }^{[13]}$ [Table 6]

Also Saudek et al suggested that red cell age was unlikely to be a significant factor in explaining the changes in $\mathrm{HbA}_{1} \mathrm{C}$ levels during the treatment of IDA and believed that the reported differences in $\mathrm{HbA}_{1} \mathrm{C}$ concentrations before and after iron supplementation were due to differences in the laboratory methods used for measuring $\mathrm{HbA}_{1} \mathrm{C} \cdot{ }^{[24]}$ Ferritin is a storage form of iron, and it reflects the true iron status [WHO]. In our study, serum ferritin as well as serum iron level was indirectly proportional to $\mathrm{HbA}_{1} \mathrm{C}$. As explained previously, in IDA, ferritin is decreased with increase in the red cell life span which is associated with increased $\mathrm{HbA}_{1} \mathrm{C}$. This goes in hand with other study results of Shanthi et al and Raj et al. ${ }^{[15,25]}$

We also analyzed $\mathrm{HbA}_{1} \mathrm{c}$ results in different degrees of anemia and found that $\mathrm{HbA}_{1} \mathrm{C}$ level increases as severity 
of anemia worsens. This result of ours was in accordance with the results of Silva et al. ${ }^{[23]}$ [Table 7]

Because the above studies were performed mostly in subjects mostly in individuals without diabetes, they could not conclude whether the presence of IDA affect $\mathrm{HbA}_{1} \mathrm{C}$ level at the cutoff point of $<6.5 \%$ vs $\geq 6.5 \%$ the newly recommended diagnostic cutoff point for diabetes by the ADA. This study has few limitations. They are small sample size and the results were obtained from a single centre and with a cross-sectional design, we couldn't follow up after iron therapy.

\section{Conclusion}

Presence of IDA spuriously elevates $\mathrm{HbA}_{1} \mathrm{C}$ level independent of blood glucose concentration in both diabetics and non-diabetics. Hence prior to alteration of treatment regimen based on $\mathrm{HbA}_{1} \mathrm{C}$ for diabetes, IDA should be diagnosed and corrected. Also this study suggests concurrent measurement of iron, $\mathrm{Hb}, \mathrm{HbA}_{1} \mathrm{C}$ is critical to correctly interpret glycemic status in Indian population where IDA is highly prevalent.

\section{Acknowledgement}

I would like to thank our Dean Dr. A. Sundaram, SRM Medical College Hospital and Research Centre for his support throughout the study. Am thankful to all the participating people for their cooperation.

\section{References}

1. American Diabetes Association. Classification and diagnosis of diabetes. Diabetes care. 2015;38:S8-16

2. World Health Organization. Use of glycated haemoglobin (HbA1c) in diagnosis of diabetes mellitus: abbreviated report of a WHO consultation.

3. Cavagnolli G, Comerlato J, Comerlato C, Renz P, Gross JL, Camargo JL. HbA1c measurement for the diagnosis of diabetes: is it enough?. Diabetic Medicine. 2011;28(1):31-5.

4. Thomas MC, MacIsaac RJ, Tsalamandris C, Power D, Jerums G. Unrecognized Anemia in Patients With Diabetes A cross-sectional survey. Diabetes care. 2003;26(4):1164-9.

5. Tong PC, Kong AP, So WY, Ng MH, Yang X, Ng MC, et al. Hematocrit, independent of chronic kidney disease, predicts adverse cardiovascular outcomes in Chinese patients with type 2 diabetes. Diabetes care. 2006;29(11):2439-44.

6. Joss N, Patel R, Paterson K, Simpson K, Perry C, Stirling C. Anaemia is common and predicts mortality in diabetic nephropathy. QJM. 2007;100(10):641-7.

7. Christy AL, Manjrekar PA, Babu RP, Hegde A. Influence of Iron Deficiency Anemia on Hemoglobin A1C Levels in Diabetic Individuals with Controlled Plasma Glucose Levels. Iran Biomed J. 2014;18(2):88.
8. Lapolla A, Traldi P, Fedele D. Importance of measuring products of non-enzymatic glycation of proteins. Clin biochem. 2005;38(2):103-15.

9. Bain BJ, Lewis SM. Dacie and Lewis Practical Haematology. 11th ed. Edinburgh: Elsevier Churchill Livingstone, 2012. Print.

10. Hong JW, Ku CR, Noh JH, Ko KS, Rhee BD, Kim DJ. Association between the presence of iron deficiency anemia and hemoglobin A1c in Korean adults: the 2011-2012 Korea National Health and Nutrition Examination Survey. Medicine. 2015 May 1;94(20):e825.

11. Sinha N, Mishra TK, Singh T, Gupta N. Effect of iron deficiency anemia on hemoglobin A1c levels. Ann Lab Med. 2012;32(1):17-22.

12. Cawood TJ, Buckley U, Murray A, Corbett M, Dillon D, Goodwin B, et al. Prevalence of anaemia in patients with diabetes mellitus. Irish J Med Sci. 2006;175(2):25-7.

13. Stevens PE, O'Donoghue DJ, Lameire NR. Anaemia in patients with diabetes: unrecognised, undetected and untreated? Current medical research and opinion. 2003;19(5):395-401.

14. Kalasker V, Kodliwadmath MV, Bhat H. Effect of iron deficiency anemia on glycosylated hemoglobin levels in nondiabetic Indian adults. Int J Med Hlth Sci. 2014;3(1):40-3.

15. Shanthi B, Revathy C, Manjula Devi AJ, et al. Effect of iron deficiency on glycation of haemoglobin in nondiabetics. J Clin Diagn Res. 2013;7(1):15-17.

16. El-Agouza I, Abu Shahla A, Sirdah M. The effect of iron deficiency anaemia on the levels of haemoglobin subtypes: possible consequences for clinical diagnosis. Clin Lab Haematol. 2002;24(5):285-9.

17. Zoppini G, Targher G, Chonchol M, Negri C, Stoico V, Pichiri I, et al. Anaemia, independent of chronic kidney disease, predicts all-cause and cardiovascular mortality in type 2 diabetic patients. Atherosclerosis. 2010;210(2):575-80.

18. Tarim ÖM, Küçükerdogan AY, Günay ÜN, Eralp ÖZ, Ercan I. Effects of iron deficiency anemia on hemoglobin A1c in type 1 diabetes mellitus. Pediatr Int. 1999;41(4):357-62.

19. Ng JM, Cooke M, Bhandari S, Atkin SL, Kilpatrick ES.The effect of iron and erythropoietin treatment on the A1C of patients with diabetes and chronic kidney disease. Diabetes Care. 2010;33(11):2310-3.

20. Sharif F, Sazandeh SH. Serum ferritin in type 2 diabetes mellitus and its relationship withHbA1c. Acta Medica iranica. 2004;42(2):142-5.

21. Ford ES, Cowie CC, Li C, Handelsman Y, Bloomgarden ZT. Iron-deficiency anemia, non-iron deficiency anemia and HbA1c among adults in the US. J Diabetes. 2011;3(1):67-73.

22. Coban E, Ozdogan M, Timuragaoglu A. Effect of iron deficiency anemia on the levels of hemoglobin A1C in nondiabetic patients. Acta Haematol. 2004;112(3):126-8. 
23. Silva JF, Pimentel AL, Camargo JL. Effect of iron deficiency anaemia on HbAlc levels is dependent on the degree of anaemia. Clinical Biochemistry. 2016;49(1):117-20.

24. Saudek CD, Herman WH, Sacks DB, Bergenstal RM, Edelman D, Davidson MB. A new look at screening and diagnosing diabetes mellitus. J Clin Endocrinol Metab. 2008;93(7): 2447-53.

25. Raj S, Rajan GV; Correlation between elevated serum ferritin and HbA1c in type 2 diabetes mellitus. Int J Res Med Sci. 2013; 1(1): 12-15.

*Corresponding author:

Dr. Lavanya Rajagopal, Door no. 902, B-Block, SRM Medical Staff Quarters, SRM Medical College Hospital and Research Centre, Kattankulathur, Pincode: 603203, Chennai, INDIA

Phone: +91 8754131339

Email: drrlavan@yahoo.co.in

Date of Submission : 10.01.2017

Financial or other Competing Interests: None. 